UDC 621.793.6

DOI 10.36910/6775-2313-5352-2020-17-18

D.B. Sereda, Ph.D.

Dnipro State Technical University

\title{
OPERATIONAL PROPERTIES OF CONSTRUCTION MATERIALS WITH PROTECTIVE COATINGS OBTAINED UNDER NON-STATIONARY TEMPERATURE CONDITIONS
}

\begin{abstract}
The structure and phase composition of chromium-alloy coatings consisting of the following phases are investigated in the work: when boron doping the coating on brass C68700 consists of phases: $\mathrm{Cu}_{3} \mathrm{Al}, \mathrm{CuB}, \mathrm{CuZn_{2 }}$ and zones of solid solution $\mathrm{Cr}, \mathrm{Al}, \mathrm{B}$ in copper; during titanium doping $\mathrm{Cu}_{3} \mathrm{Al}$ and $\mathrm{CuAl}$ phases in the transition zone: phases $\mathrm{CuTi}$ and $\mathrm{CuTi} \mathrm{i}_{2}$ When tested on $\mathrm{A572}$ steels, in conditions of sliding friction, the best wear resistance among the considered protective coatings are doped with titanium and boron. Their wear resistance is 1,8-2,1 times higher than that of coatings obtained under isothermal conditions. Under non-stationary temperature conditions, the microhardness reaches the following values: when doped with boron $H_{100}=16500-17500 \mathrm{MPa}$, when doped with silicon $H_{100}=13500-14500 \mathrm{MPa}$, when doped with titanium $H_{100}=15000-16000$ $M P a$. The obtained results correlate with the indicators of wear resistance. A comparative analysis of the corrosion resistance of protective coatings obtained under non-stationary temperature conditions and isothermal conditions shows that they have a weight loss of 1.7-2.1 times less. It was found that when tested in a $30 \%$ aqueous solution of sulfuric acid, all protective coatings have good stability. Thus, when doped with boron, the weight loss is $15,2 \mathrm{~g} / \mathrm{m}^{2}$, npu when doped with silicon $-10,8 \mathrm{~g} / \mathrm{m}^{2}$, and when doped with titanium - $-9,9 \mathrm{~g} / \mathrm{m}^{2}$.
\end{abstract}

Keywords: diffusion, , microstructure, phase, micro hardness, non-stationary temperature conditions, wear resistance.

\section{Introduction.}

Modern development of science and technology requires the creation of materials capable of working effectively in conditions of long-term cyclic action of high-temperature aggressive environments. Such materials must be heat- and erosion-resistant, have high heat resistance and low density, resistance to high stress and thermal shock. Many researchers note that such materials can be alloys based on intermetallic compounds [1-4].

Alloys based on intermetallics - a new class of materials, which by their structure occupy an intermediate position between metals and ceramics. They have a complex crystal structure with the presence of up to $30 \%$ of the covalent component in the interatomic bonds, which determines their unique physical and mechanical properties [5]. Intermetallic compounds or intermetallics are chemical compounds of metals related to each other:

$$
m M e+n M e^{\prime} \rightarrow M e_{m} M e^{\prime}{ }_{n},
$$

where $M e$ and $M e^{\prime}-$ metals;

$m$ and $n$-stoichiometric coefficients.

The general classification of intermetallics includes daltonides (having a purely definite composition), bertolides (variable composition) and the Kurnakov phase. To date, more than 1,500 intermetallic compounds have been identified and described, which form about 200 different types of crystalline structures [6]. The most promising structural materials include the following types of intermetallics [6]:

1) phases of type $A_{3} B$ with a cubic crystal lattice $\left(\mathrm{Ni}_{3} \mathrm{Al}, \mathrm{Ni} \mathrm{i}_{3} \mathrm{Si}, \mathrm{Ni} i_{3} \mathrm{Fe}, \mathrm{Ni}_{3} \mathrm{Mn}, \mathrm{Zr} r_{3} \mathrm{Al}\right)$;

2) phases of type $A_{3} B$ with hexagonal lattice $\left(\mathrm{Ti}_{3} A l, T i_{3} S n\right)$; $\mathrm{Nb}_{3} \mathrm{Al}$;

3) aluminides of the $\mathrm{Me}_{3} \mathrm{Al}\left(\mathrm{A}_{3} \mathrm{~B}\right)$ type with a structure different from the first two $\left(\mathrm{Fe}_{3} \mathrm{Al}\right.$,

4) aluminides of the $\mathrm{MeAl}_{3}$ type $\left(\mathrm{NbAl}_{3}, \mathrm{NiAl}_{3}, \mathrm{TaAl}_{3}, \mathrm{TiAl}_{3}, \mathrm{ZrAl}_{3}\right)$;

5) phases of the AB type (TiAl, CuAu, NiAl, CoTi, CoZr, NiBe, FeAl, FeCo, TiNi);

6) triple aluminides: $A l_{1-x-y} \mathrm{Ti}_{x} \mathrm{Me} e_{y}$, де $\mathrm{Me}-\mathrm{Co}, \mathrm{Cr}, \mathrm{Cu}, \mathrm{Fe}, \mathrm{Mn}, \mathrm{Ni}$;

7) Laves triple phases: (TaFeAl, TaNiAl, NbNiAl). 
High-temperature intermetallic alloys must have the following performance properties: high heat-resistant and heat-resistant specific characteristics, sufficient wear resistance, acceptable ductility and manufacturability, high corrosion and oxidation resistance. Surface saturation with aluminum, chromium, zinc and other elements refers to diffusion saturation with metals. The product, the surface of which is enriched with these elements, acquires valuable properties, including high heat resistance, corrosion resistance, increased wear resistance and hardness [7-10].

Depending on the method of transferring the diffusion element to the saturated surface, the following main methods of diffusion metallization are distinguished: immersion in molten metal if the diffusion element has a low melting point; saturation from molten salts containing a diffusing element (with and without electrolysis); saturation from the sublimated phase due to the evaporation of the diffusing element; saturation from the gas phase (contact and non-contact method), consisting of halogen compounds of the diffusing element [10-14].

Among the methods of surface hardening, chromium-alcohol coatings obtained by various methods of chemical and thermal treatment are widely used. In this regard, for Ukraine, it is relevant to develop new methods of chemical-thermal treatment, which make it possible to regulate the composition and structure of protective coatings, to provide the necessary performance characteristics with a minimum time of their formation. Such technologies are based on the phenomenon of selfpropagating high-temperature synthesis [15-18].

\section{Materials and methods of research.}

The purpose of the work was to increase the corrosion resistance of brass C68700 in the conditions of SHS. Chemical-thermal treatment was carried out in an open-type reactor $\left(\mathrm{P}=10^{5} \mathrm{~Pa}\right)$ in the operating temperature range of $900-1100^{\circ} \mathrm{C}$. The duration of isothermal exposure varied from 30 to 60 minutes.

Surface preparation of the samples consisted of successive grinding, polishing and degreasing in acetone. Initiation of the process of thermal autoignition was carried out by preheating the resistance in the furnace to the temperature of the beginning of the exothermic reaction $(\mathrm{t} *)$.

To analyze the phase composition of the coatings, an X-ray diffractometer DRON-3M was used. Investigation of the elemental composition of coatings was carried out by micro-X-ray spectral analysis using the JEOL microprobe "Superprob-733".

The tests for corrosion resistance are carried out on cylindrical samples with a diameter of 10 $\mathrm{mm}$ and a height of $20 \mathrm{~mm}$. The samples of brass C68700 are investigated in 30\% - aqueous solutions of hydrochloric, sulfuric and nitric acids at a temperature of $20^{\circ} \mathrm{C}$. Before and after the test, the samples were washed with acetone, dried and solved on analytical scales for 7 days every 24 hours with accuracy up to $1 \mathrm{mg}$ and the mass loss per unit surface of the sample under the influence of corrosion is calculated [19].

The considered C68700 brass in its composition consists of $\alpha+\beta$ phases, where there is more $\beta$-phase. Brass has good corrosion resistance in normal atmospheres as well as in maritime climates. At the same time, brass containing less than $15 \% \mathrm{Zn}$ is close to copper in corrosion resistance. The corrosion rate of bronze in atmospheric conditions does not exceed $0.001 \mathrm{~mm} /$ year; in fresh water, the corrosion rate is insignificant and at a temperature of $20^{\circ} \mathrm{C}$ is $0.0025 \ldots 0.025 \mathrm{~mm} /$ year.

Brass corrodes intensively under the influence of mineral acids (nitric, hydrochloric). Sulfuric acid acts on brass much more slowly, but in the presence of oxidants $\{\mathrm{K} 2 \mathrm{Cr} 2 \mathrm{O} 7, \mathrm{Fe} 2$ (S04) 3$\}$, the corrosion rate increases by two orders of magnitude. Bars are quite stable in alkali solutions (with the exception of ammonia) and in concentrated solutions of neutral salts.

Hydrogen sulphide is highly corrosive to brass. At the same time, brass with a high zinc content (over 30\%) is more resistant to hydrogen sulfide environments than brass with a low zinc content. Corrosion resistance studies are performed using corrosive materials that simulate the intended application:

- pumps for pumping acid in titanium production;

- bearing assemblies at special equipment facilities of the rocket-space and defense industries;

- for the manufacture of parts of a simple configuration for critical purposes and fittings for marine shipbuilding, operating at temperatures up to $300^{\circ} \mathrm{C}$ of massive parts, propellers and their blades.

Research materials and methods. Considered brass C68700, according to its composition, finds itself within the $\alpha+\beta$ phases, where there is more $\beta$-phase. Brass has good 
corrosion resistance in the ordinary atmosphere, as well as in the marine climate. At the same time brass containing less than $15 \% \mathrm{Zn}$, in corrosion resistance is close to copper.

The bronze corrosion rate under atmospheric conditions does not exceed $0,001 \mathrm{~mm} /$ year; in fresh water, the rate of corrosion is insignificant and at a temperature of $20{ }^{\circ} \mathrm{C}$ is $0,0025 \ldots 0,025$ $\mathrm{mm} /$ year.

Brasses intensively corrode under the influence of mineral acids (nitric, hydrochloric). Sulfuric acid acts on brass much slower, but in the presence of oxidants $\left\{\mathrm{K}_{2} \mathrm{Cr}_{2} \mathrm{O}_{7}, \mathrm{Fe}_{2}\left(\mathrm{SO}_{4}\right)_{3}\right\}$, the corrosion rate increases by two orders of magnitude. Bars are sufficiently stable in solutions of alkalis (with the exception of ammonia) and in concentrated solutions of neutral salts.

Hydrogen sulfide provides strong corrosive action on brass. At the same time, brass with high zinc content (more than 30\%) is more stable in the hydrogen sulfide medium than brass with low zinc content. For corrosion resistance research, corrosive materials are used that imitate the intended applications:

- pumps for acid transfer in the production of titanium;

- bearing units on objects of special equipment in rocket space and defense industries;

- for the manufacture of simple configuration of parts for responsible purposes and armature of marine shipbuilding, operating at temperatures up to $300{ }^{\circ} \mathrm{C}$ of massive parts, propellers and their blades.

To enhance the corrosion resistance of brass, C68700 requires a protective coating containing elements that form passive films. In this case, upon reaching the potential of ionic passivation, oxide films of the composition: $\mathrm{Cr}_{2} \mathrm{O}_{3}, \mathrm{Al}_{2} \mathrm{O}_{3}, \mathrm{TiO}_{2}, \mathrm{SiO} 2$ which protect the metal from destruction, are formed.

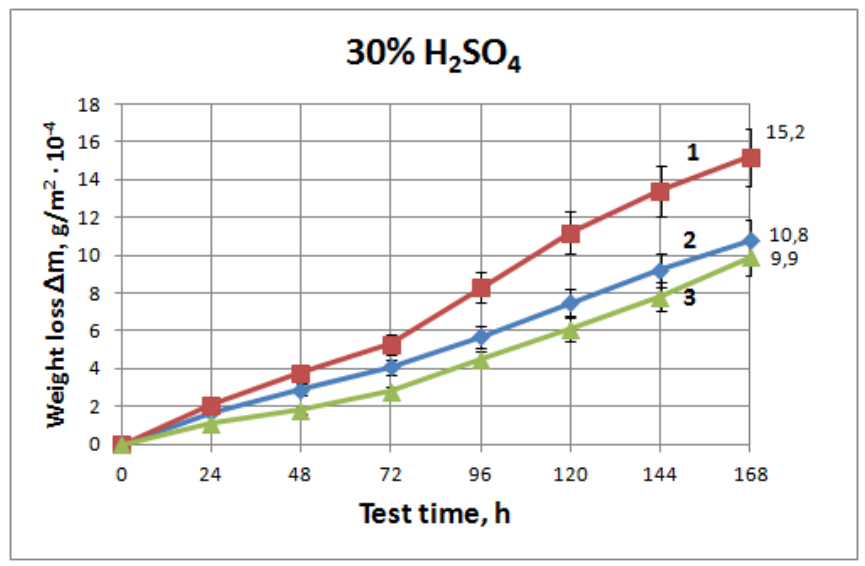

Fig. 1. Comparative characteristics of indicators of weight loss

When testing in $30 \%$ of aqueous sulfuric acid solution, good resistance to all protective coatings. Thus, with boron doping, the mass loss is $15,2 \mathrm{~g} / \mathrm{m}^{2}$, with silicon doping $-10,8 \mathrm{~g} / \mathrm{m}^{2}$, and when titanium alloy $-9,9 \mathrm{~g} / \mathrm{m}^{2}$. Comparative analysis of corrosion resistance (Fig. 1) of protective coatings obtained in isothermal conditions, shows that they have a weight loss of 1,7-2,1 times more.

The obtained results can be explained by the formation of doped phases on the surface, which leads to surface passivation in aggressive environments. It is also possible to assume the effect of electrochemical inhibition of anodic dissolution of metals at a higher concentration of alloying elements in comparison with coatings obtained in isothermal alloy coatings, which indicates the absence of micro cracking. It is known that mechanical stresses (in this case compressive residual stresses) affect the corrosion behavior of metals due to the production of additional energy by the structural material due to the fact that the level of residual stresses in coatings obtained under thermal ignition of SHS-charge is higher. As a result, the probability of micro cracking of passive oxide films decreases, which leads to increased corrosion resistance.

The test results of steel samples for wear under sliding friction on the friction machine SMT-1 are shown in Fig. 2. 

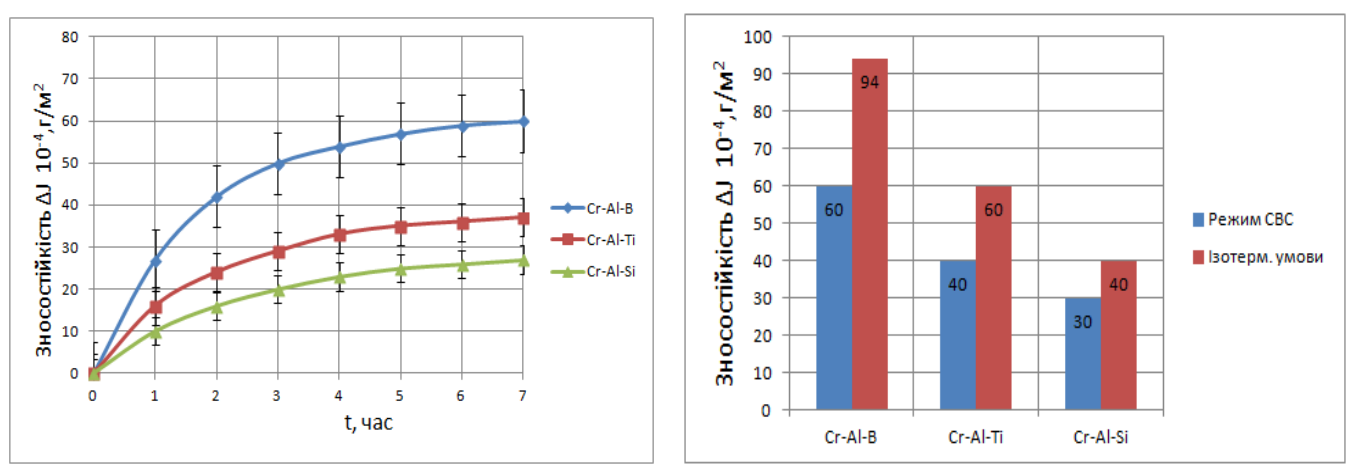

Fig. 2. Wear resistance of protective coatings on steel A572 tp $=10500 \mathrm{C}, \tau \mathrm{v}=60 \mathrm{~min}$, (friction testing machine SMT-1)

When tested under sliding friction conditions, titanium and boron alloys have the best wear resistance among the considered. Their wear resistance is $1,8-2,1$ times higher than that of coatings obtained under isothermal conditions.

This can be explained by the higher microhardness, which is for coatings obtained in isothermal conditions during doping with boron $\mathrm{H}_{100}=15000$ - $15500 \mathrm{MPa}$, when doping with silicon $\mathrm{H}_{100}=12500-13000 \mathrm{MPa}$, when doping with titanium H100 = $14000-14500 \mathrm{MPa}$.

In the conditions of SHS the microhardness reaches the following values: at doping by boron $\mathrm{H}_{100}=16500-17500$ MPas, at doping by silicon $\mathrm{H}_{100}=13500-14500$ MPas, at doping by titanium $\mathrm{H}_{100}=15000-16000$ MPas. The obtained results correlate with the indicators of wear resistance. It is known that the wear of the metal is accompanied by plastic and elastic deformations of the surface layer, chipping and shear of individual metal particles of the surfaces and fatigue failure.

\section{Conclusions.}

1. Received diffusion coatings from composite saturating powder media consisting of both pure metal powders and their oxides. The wear resistance of protective coatings was determined when tested on the machine rubbing SMT-1.

2. When testing in $30 \%$ of aqueous sulfuric acid solution, good resistance to all protective coatings. Thus, with boron doping, the mass loss is $11,7 \mathrm{~g} / \mathrm{m}^{2}$, with silicon doping $-10,8 \mathrm{~g} / \mathrm{m}^{2}$, and when titanium alloy $-12,4 \mathrm{~g} / \mathrm{m}^{2}$. Comparative analysis of corrosion resistance of protective coatings obtained in isothermal conditions, shows that they have a weight loss of 1,7-2,1 times more.

\section{References}

1. Molyar A.G., Kotsyuba A.A., Bychkov A.S., Nechiporenko O.Yu. Structural materials in aircraft construction. Kiev: KVITs, 2015.400 p. ISBN 978-617-697-038-8.

2. Sanin F.P., Kuchma L.D., Jur E.O., Sanin A.F. Solid propellant rocket engines. Materials and technologies. Dnepropetrovsk: Dnepropetrovsk Publishing House. un-tu, 1999. 320 p.

3. Kolachev BA Titanium alloys in the design and production of aircraft engines and aerospace technology: monograph / Pod. ed. A.G. Bratukhina. Moscow: MAI Publishing House, 2001.411 p. ISBN 5-7035-2463-6.

4. Belov A.F., Benediktova G.P., Viskov A.S. et al. Structure and properties of aviation materials / Ed. A. F. Belova, V. V. Nikolenko. Moscow: Metallurgy, 1989.368 p.

5. Bannykh O.A., Povarova K.B. Intermetallides - a new class of light heat-resistant and heatresistant materials. Light alloy technology. 1992. No. 5. S. 26-32.

6. Sinelnikov V.S., Podergin V.A., Rechkin V.N., Aluminides. Kiev: Nauk. Dumka, 1965.243 p.

7. Merzhanov A.G. Solid flames: discovery, concepts and horizons of cognition. Combust. Sci. and Technol., 1994, v. 98, № 4-6, p. 307-336.

8. Merzhanov A.G., Rogachev A.S. Phase and structure transformations during SHS.Adv. Sci. Techn. 2003, v.31, pp. 271-282

9. Chemical-thermal treatment of metals and alloys. Directory. / Borisenok G.V., Vasiliev L.A., Voroshnin L.G. and others. - Moscow: Metallurgy, 1981.- 424 p. 
10. Sereda B. Production of highly effective SHS coatings operating in oxidizing and corrosive environments / Sereda B., Sereda D., Kryglyak I. // Material science and technology - 2017. Pittsburgh. Pennsylvania USA. 2017. - P.424-429

11. Sereda B. Simulation and modeling of metallurgical phenomena produced on pressing in SHScondition/ Sereda B., Sereda D., Kovalenko A., Kryglyak I. // Material science and technology - 2017. Pittsburgh. Pennsylvania USA. 2017. - P.727-732

12.Establishment of the relationship between the microstructure characteristics and the heat resistance of silicate coatings obtained under SHS conditions/ Sereda B., Sereda D., Sereda I.// Material science and technology - 2017. Pittsburgh. Pennsylvania USA. 2017. - P.412-416

13.Sereda B. Corrosion Resistance and Mechanical Properties Zinc Coating Sheet Steels, Received in Conditions of Self-propagating High Temperature Synthesis / Sereda D., Sereda B. // Material science and technology- 2016. Salt Lake City, Utah USA 2016. - P.825-829.

14.Sereda B. Development of Protective Coatings Formulations Based on Boron for Units Operating at High Temperatures in Metallurgy / Sereda D., Sereda B. // Material science and technology- 2016. Salt Lake City, Utah USA 2016. - P.931-934.

15. Sereda B. Modeling deformation in material processing and laws of phasic by SHS pressing intermetallics alloys / Sereda D., Sereda B. // Material science and technology. Columbus. Ohio, USA 2015. - P.611-617.

16. Sereda B. Aluminized Multifunctional Coating on Steel in SHS Condition./ Sereda D., Sereda B. //Material science and technology. Pittsburgh. Pennsylvania, USA 2014. - P.482-486.

17. Sereda B. Modeling deformation in material processing and laws of phasic by SHS pressing intermetallics alloys / Sereda D., Sereda B. //Material science and technology 2015. Conference and Exhibition. Columbus. Ohio, USA. 1827p. P.611-617 -SCOPUS

18. Sereda B., Sereda D. Kinetiks formation of aluminized multifunctional coating on steel in SHS condition. Material science and technology. Columbus, Ohio, USA. 2011.-P.1667-1671.

19.Zhuk N.P. Course of the theory of corrosion and protection of metals / N.P. Zhuk // - M .: Metallurgy, 1976. - $472 \mathrm{p}$.

Середа Д.Б., к.т.н.

Дніпровський державний технічний університет

\section{ЕКСПЛУАТАЦІЙНІ ВЛАСТИВОСТІ КОНСТРУКЦІЙНИХ МТАЕРІАЛІВ ІЗ ЗАХИСНИМ ПОКРИТТЯМ ОТРИМАНИМИ ПРИ НЕСТАЦІОНАРНИХ ТЕМПЕРАТУРНИХ УМОВАХ}

В роботі досліджено структура, i фазовий склад хромоалітованних покриттів, щзо складаються з наступних фаз: при легуванні бором покриття на латуні С68700 складається з фаз: $\mathrm{Cu}_{3} \mathrm{Al}, \mathrm{CuB}, \mathrm{CuZn}{ }_{2}$ та зони твердого розчину $\mathrm{Cr}, \mathrm{Al}, \mathrm{B}$ у міді; при легуванні титаном, фази Cu $\mathrm{Al}$ та CuAl у перехідній зоні: фази СиTі та СиТі. . При випробуваннях на стали А572, в умовах тертя ковзання найкращу зносостійкість серед розглянутих захисних покриттів мають леговані титаном та бором. Їх зносостійкість в 1,8 - 2,1 раз вища, чим у покриттів, отриманих при ізотермічних умовах. При нестаціонарних температурних умовах мікротвердість досягає наступних значень: при легуванні бором $H_{100}=16500-17500$ МПа, при легуванні кремнісм $H_{100}=13500-14500$ МПа, при легуванні титаном $H_{100}=15000-16000$ МПа. Отримані результати корелюють з показниками зносостійкості. Порівняльний аналіз корозійної стійкості захисних покриттів отриманих при нестачіонарних температурних умовах та ізотермічних умовах, показуе, щзо вони мають втрату ваги в 1,7-2, 1 рази меншу. Встановлено, що при випробуванні в $30 \%$ водяному розчині сірчаної кислоти добру стійкість мають усі захисні покриття. Так, при легуванні бором втрата маси складає

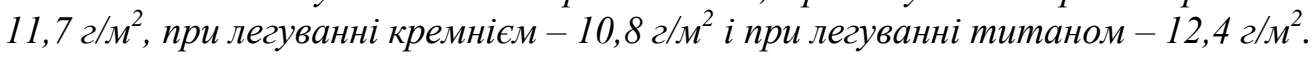

Keywords: дифузія, мікроструктура, фаза, мікротвердість, нестаціонарні температурні умови, зносостійкість. 
Середа Д.Б., к.т.н.

Днепровский государственный технический университет

\section{ЭКСПЛУАТАЦИОННЫЕ СВОЙСТВА КОНСТРУКЦИОННЫХ МТАЕРИАЛОВ С ЗАЩИТНЫМИ ПОКРЫТИЯМИ ПОЛУЧЕННЫМИ ПРИ НЕСТАЦИОНАРНЫХ ТЕМПЕРАТУРНЫХ УСЛОВИЯХ}

В работе исследованы структура и фазовый состав хромоалитированных покрытий состоящий из следующих фаз: при легировании бором покрытия на латуни C68700 coстоит из фаз: $\mathrm{Cu}_{3} \mathrm{Al}, \mathrm{CuB}, \mathrm{CuZn_{2 }}$ и зоны твердого раствора $\mathrm{Cr}, \mathrm{Al}, \mathrm{B}$ в меди при легировании титаном, фазы Cu3Al и CuAl в переходной зоне: фазы CuTi и CuТi. . При испытаниях на стали A572, в условиях трения скольжения лучшую износостойкость среди рассмотренных защитных покрытий имеют легированные титаном и бором. Их износостойкость в 1,8 - 2,1 раз выше, чем у покрытий, полученных при изотермических условиях. При нестационарных температурных условиях, микротвердость достигает следующих значений: при легировании бором Н100 = 16500 - 17500 МПа, при легировании кремнием Н100 = $13500-14500$ МПа, при легировании титаном Н100 = $15000-16000$ МПа. Полученные результать коррелируют с показателями износостойкости. Сравнительный анализ коррозионной стойкости защитных покрытий полученных при нестационарных температурных условиях и изотермических условиях, показывает, что они потерю веса в 1,7-2, 1 раза меньше. Установлено, что при испытании в 30\% водном растворе серной кислоты хорошую стойкость имеют все защитные покрытия. Так, при

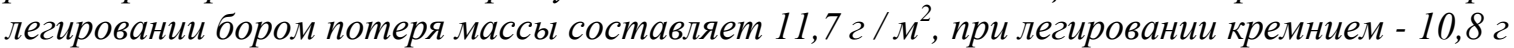
$/ \mathrm{M}^{2}$ и при легировании титаном - 12,4 г / $\mathrm{M}^{2}$.

Keywords: диффузия, микроструктура, фаза, микротвердость, нестаиионарный температурный режим, износостойкость. 